\title{
The early polychelidan lobster Tetrachela raiblana and its impact on the homology of carapace grooves in decapod crustaceans
}

\author{
Denis Audo ${ }^{1,5}$, Matúš Hyžný2,3, Sylvain Charbonnier ${ }^{4}$ \\ ${ }^{1}$ UMR CNRS 6118 Géosciences, Université de Rennes I, Campus de Beaulieu, avenue du général Leclerc, 35042 \\ Rennes cedex, France \\ ${ }^{2}$ Department of Geology and Palaeontology, Faculty of Natural Sciences, Comenius University, Bratislava, \\ Slovakia \\ ${ }^{3}$ Geological-Palaeontological Department, Natural History Museum Vienna, Vienna, Austria \\ ${ }^{4}$ Muséum national d'Histoire naturelle, Centre de Recherche sur la Paléobiodiversité et les Paléoenvironnements \\ (CR2P, UMR 7207), Sorbonne Universités, MNHN, UPMC, CNRS, 57 rue Cuvier F-75005 Paris, France \\ ${ }^{5}$ E-mail: denis.audo@edu.mnhn.fr
}

Keywords: Austria, Crustacea, Decapoda, Depth, Homology, Italy, Lagerstätte, Palaeoenvironment, Palaeoecology, Triassic

\begin{abstract}
Polychelidan lobsters, as the sister group of Eureptantia (other lobsters and crabs), have a key-position within decapod crustaceans. Their evolutionary history is still poorly understood, although it has been proposed that their Mesozoic representatives largely inhabited shallow-marine environment and only later sought refuge in deep water. This view has recently been challenged, so the evolutionary history of polychelidans is in a need of re-appraisal. The earliest representatives, such as Tetrachela from the Late Triassic of Austria and Italy, are of great importance because of their potential in investigation of life habits of early polychelidans. Tetrachela lived in a relatively deep water, however, its well-developed eyes suggest an environment where light was still present. With its massive dorsoventrally flattened body plan, Tetrachela was probably benthic; the shape of its mandible and stocky first pereiopods suggest it was a scavenger and/or fed on slowly moving or sedentary animals. The carapace of Tetrachela has a peculiar groove pattern, which leads us to redefine some elements of the nomenclature of grooves used for polychelidans. Based on the present revision we propose that the second incision and its associated groove correspond to the hepatic groove, not the postcervical or the branchiocardiac grooves as interpreted previously. This revision allows us to review the homologies of cephalothoracic groove between polychelidans and other notable groups of decapod crustaceans.
\end{abstract}

\section{Contents}

Introduction .............................................. 41

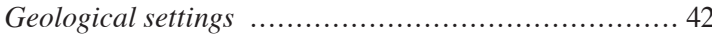

Material and methods ....................................... 42

Systematic palaeontology ..................................... 43

Discussion .................................................... 49

Nomenclature of grooves ............................... 49

Comparison with other Carnian polychelidans ............ 51

Homologies of grooves between polychelidans and

some other decapods.

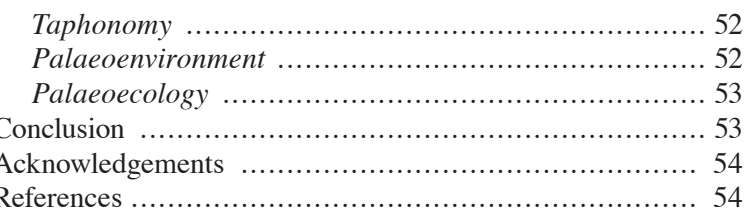

\section{Introduction}

Polychelidan lobsters can be considered as the coelacanths of decapod crustaceans: fossil species were the first to be discovered (Desmarest, 1817), were morphologically diverse, and lived in various palaeoenvironments (Audo et al., 2014a, c; Bravi et al., 2014; Jauvion et al., 2016); extant species, on the contrary, were discovered later (Heller, 1863), are morphologically less diverse, and restricted to deepwater environments (Galil, 2000; Ahyong, 2009). This peculiar distribution was tentatively explained by Beurlen (1931), who postulated that polychelidans first inhabited shallow waters and later sought refuge in deep waters. This view was followed by Glaessner (1969) and refined by Ahyong (2009). However, this model was recently criticized by Audo et al. (2014b, in press). More importantly, polychelidan lobsters have played a key role in decapod phylogeny, because Polychelida is considered to be the sister taxon to eureptantians (Scholtz and Richter, 1995; Ahyong and O’Meally, 2004; Bracken-Grissom, et al. 2014).

For these reasons, it is important to have a better understanding of the evolutionary history of polychelidan lobsters, including the significance of their earliest fossil occurrences. Indeed, these early species might give us 
insights into the original life habits of polychelidans and also yield important morphological characters for the phylogenetic study not only of polychelidans but also decapod crustaceans. Polychelidan earliest occurrences date back to the Late Triassic (Carnian). Two species are known from that time interval; Coleia uzume Karasawa, Takahashi, Doi and Ishida, 2003, has been described from Japan (Karasawa et al., 2003), and Tetrachela raiblana (Bronn, 1858) from the Alps on both sides of the current boundary between Italy and Austria. Both species are insufficiently known, partly because of the preservation of the available material. Tetrachela raiblana has so far not been adequately documented, probably because most specimens are incompletely preserved, often without the carapace, which presents numerous characters useful in systematic palaeontology. In this respect, detailed documentation of available carapaces presented herein fills the gap in the knowledge. As shown further below, the carapace in T. raiblana is especially interesting because it possesses a peculiar groove pattern (Beurlen and Glaessner, 1930: fig. 11) that at a first glance is different from that of other polychelidans (the groove pattern on C. uzume is indistinct due to the preservation). The significance of T. raiblana was recognized by Ahyong (2009), who used that species as the outgroup (or reference point) of his phylogenetic analysis of polychelidan lobsters.

The present contribution reviews $T$. raiblana and assesses its significance based upon the available material, including the only known surviving syntype and some especially well-preserved specimens. This revision leads to a better understanding of the homologies of cephalothoracic grooves between polychelidans and other decapods. We also propose an updated nomenclature for grooves based upon our interpretations. Finally, we briefly discuss the palaeoenvironment and palaeoecology of T. raiblana.

\section{Geological settings}

The sediments of the Raibl (Cave del Predil) and Polzberg lagerstätten were deposited during the Carnian (Late Triassic). At that time, the Alpine zone was located at the western extremity of the Neotethys Ocean, and both localities were located on the margin of the Hallstatt-Meliata Ocean, a small branch of the Neotethys (Hornung et al., 2007).

Sediments exposed at both localities are approximately coeval and were deposited during what is known as the Carnian Pluvial Event (Hornung et al., 2007), a biological crisis linked to a sudden climatic perturbation which led to the demise of rimmed carbonate platforms (Keim et al., 2001) and a switch to carbonate or mixed ramps (Bosellini et al., 2003).

Raibl Beds (Cave del Predil). The Raibl Beds were discovered due to the nearby mining for lead, iron, and zinc that probably started in the Roman period (Boué, 1835; Nuova Raibl Soc. coop., 2016). The Lagerstätte of Raibl is represented by oil shales (bituminösen Schiefer: Bronn, 1858; see also Boué, 1835) also referred to as fish beds (Suess and Mojsisovics, 1867), which were probably deposited in deep water in a basinal environment (Rettori et al., 1998; de Zanch et al., 2000). This Lagerstätte has yielded fragments of plants and several species of fishes first mentioned by Boué (1835) and later described by Bronn (1858). It also has yielded several decapod crustaceans, including Tetrachela raiblana, Antrimpos crassipes (Bronn, 1858) and Bombur aonis Bronn, 1858. Among fishes, one species, Thoracopterus niederristi Bronn, 1858 also occurs at the Polzberg locality (Griffith, 1977).

Polzberg Lagerstätte. The Reingraben shales are exposed at the Polzberg Lagerstätte. This Lagerstätte has regularly been associated and described with the nearby Lunz Lagerstätte, although these two differ in age, environment, and taphonomic pathways (Forchielli and Pervesler, 2013). The Polzberg Lagerstätte (sensu Forchielli and Pervesier, 2013) is characterized by its low energy setting (no bottom currents), occasional low-oxygen levels indicated by accumulations of the juvenile bivalves Halobia (McRoberts, 2001; Hopkin and McRoberts, 2005). The Polzberg Lagerstätte has yielded a diverse fauna of fishes (Griffith, 1977), ammonites (Glaessner, 1931), and a rich fauna of arthropods. Decapod crustaceans include Antrimpos straeleni (Glaessner, 1929), Antrimpos crassipes (also known from Cave del Predil), Clytiella spinifera Glaessner, 1931, Platychela trauthi Glaessner, 1931 and T. raiblana. In addition, two species of thylacocephalans also occur there (Glaessner, 1931).

\section{Material and methods}

This study is based upon 43 specimens. These specimens appear dark, almost black, sometimes with patches of white, on a dark grey limestone. Specimens are generally visible in ventral view, almost complete, but missing the carapace.

Specimens from the Museo Friulano di Storia Naturale (MFSNgp, Udine, Italy) and from the 
Museo Paleontologico Cittadino della Rocca di Monfalcone (MPCM, Monfalcone, Italy) were documented under cross-polarized light to enhance the contrast between the matrix and the specimen by avoiding direct reflections on the surface of the sample (Bengtson, 2000). Specimens from Harvard Museum of Comparative Zoology (MCZ, Cambridge, Massachusetts, United States of America) and Natural History Museum (NHMUK, London, United Kingdom) were photographed in natural light, in some cases, soaked in alcohol, for the NHMUK specimens. The specimens from the Geologische Bundesanstalt (GBA, Vienna, Austria) were documented in natural light and whitened by an ammonium chloride coating.

In order to compare the morphology of T. raiblana to other groups of decapod crustaceans, we also examined four specimens of extant decapod crustaceans from the zoology collections of Muséum national d'Histoire naturelle (MNHN-IU, Paris, France). Three of these specimens were collected during oceanic cruise expeditions led by the Institut de Recherche pour le Développement (IRD) and the Muséum national d'Histoire naturelle (MNHN) (Bouchet et al., 2008). These specimens were photographed under polarized white light.

\section{Systematic palaeontology}

Malacostraca Latreille, 1802

Decapoda Latreille, 1802

Pleocyemata Burkenroad, 1963

Polychelida Scholtz and Richter, 1995

Eryonoidea Haan, 1841

Coleiidae Van Straelen, 1925

Tetrachelinae Beurlen, 1930

Tetrachelidae Beurlen, 1930: 339.

Tetrachelidae - Förster, 1967: 174._- Pinna, 1968: 102. - Glaessner, 1969: R468. - Garassino and Teruzzi, 1993: 21 - Garassino et al., 1996: 36-37. Ahyong, 2009: 381. - Schweitzer et al., 2010: 45. - Karasawa et al., 2013: 98. - Audo et al., 2014a: 459.- Audo et al., 2014b: 400.

Type genus: Tetrachela Reuss, 1858 Included genera: Monotypic subfamily Occurrence: Late Triassic (Italy, Austria).

Original diagnosis by Beurlen (1930: 339). „Karapax gerundet rechteckig, mäßig stark verbreitert. Regionengliederung stark differenziert. Augen wohl entwickelt, nach vorn gerichtet, in schwachen Ausschnitten des Vorderrandes, seitlich des breiten Stirnrandes.Antennengeißeln kurz. Dritter Maxillarfuß mit verbreitertem Ischium. Telson breit gerundet; Diäresis vorhanden.“

Literal translation in modern terms. Carapace with a rounded rectangle outline, moderately widened. [Carapace] with distinct regions. Eyes well-developed, facing forward, in shallow incisions on the anterior margin, on the side of the wide frontal margin. Short antennae. Third maxilliped with a wide ischium. Telson broad and rounded. Diaeresis present.

Emended diagnosis by Pinna (1968: 102). "Cefalotorace fortemente allargato, subrettangolare. Margine anteriore largo e diritto con incisioni oculari laterali ed occhi ben sviluppati rivolti in avanti. Due incisioni laterali poco profonde. Carene assenti. Telson arrotondato e largo. Dieresi presente."

Literal translation in modern terms. Cephalothorax very wide, subrectangular. Frontal margin wide and straight with lateral ocular incisions with welldeveloped eyes facing forward. Two shallow lateral incisions. Carina lacking. Telson rounded and wide. Diaeresis present.

Emended diagnosis by Glaessner (1969: R468). "Carapace almost quadrangular, with orbital emarginations, granulate, cervical and branchiocardiac grooves strongly marked, V-shaped, postcervical groove connected with both; telson rounded, uropods with diaeresis."

Emended diagnosis by Ahyong (2009: 381). "Carapace with shallow orbits located on anterior margin; eyes well-developed, apparently directed anteriorly; without median carina anterior to cervical groove; cervical and branchiocardiac grooves distinct across carapace, not meeting, indicated at lateral margins by notches. Abdominal pleuron 2 similar to pleuron 3, not overlapping pleuron 1. Uropodal exopod with straight diaeresis. Telson rounded distally. Pereopod 1 dactylus tapering distally, longer than pollex. (Based on Glaessner 1969.)"

Emended diagnosis by Karasawa et al. (2013: 98). "Carapace almost quadrangular with orbital emarginations, dorsoventrally flattened, rostrum indistinct; antennal groove absent; cervical and branchiocardiac grooves strongly marked and V-shaped, extending to median; postcervical groove connected with cervical and branchiocardiac grooves; branchial and thoracic median carinae present; epistome and carapace not in broad contact. Pleon with axial keel and sharp demarcation between terga and 
pleura; telson subrectangular; exopod of uropods with diaeresis. Antennular stylocerite present; maxilliped 3 dactylus sharp; pereiopods 1-4 chelate; pereiopod 5 unknown."

Emended diagnosis (present work). Dorsoventrally flattened carapace subrectangular in outline in dorsal view; concave frontal margin placed more anteriorly than outer angle of ocular incision; deep U-shaped ocular incision, laterally enclosed by lateral margin, opening anteriorly; marked cervical and hepatic incisions; cervical incision deeper than hepatic incision; posterolateral angle extending slightly along s1; cervical groove cutting median line deeply; large gap between anterior and posterior part of branchial carina; posterior part of branchial carina rather short; hepatic groove distinctly merged with branchiocardiac groove, not intersected by branchial carina; telson well-rounded; third maxilliped ischium roughly kidney-shaped; first pereiopod distinctly larger than the others and rather stocky; pereiopod 5 ending in a small chela, at least in some individuals (possibly variable due to sexual dimorphism); uropodal exopod with a diaeresis forming an arc of circle.

Remarks. Tetrachelinae are assigned to Polychelida based upon their dorsoventrally flattened carapace (shield), their concave frontal margin, their pattern of cephalothoracic grooves and carina, and of their chelate pereiopods 1-4. More precisely, Tetrachelinae are placed within the diverse Coleiidae by their marked cervical and hepatic incisions, with cervical incision deeper than hepatic; the cervical groove curved medially near median line, and the presence of a diaeresis. The scaphocerite of Tetrachelinae appears to be rounded with a median carina, a character typical of Coleiidae. However, the preservation of the scaphocerite is rare and the few preserved ones are poorly preserved and therefore difficult to interpret. We note that in Ahyong (2009), Tetrachela was not placed "near Coleia" in his cladogram. It is important to observe that Ahyong (2009) used Tetrachela as the outgroup of his analysis. This implies that the position of Tetrachela in this cladogram was fixed at the base of the cladogram, by definition. Consequently, we cannot judge if Ahyong (2009) results are compatible or not with our suggestion that Tetrachelinae belongs to Coleiidae. In the analysis of Karasawa et al. (2013), Tetrachela is resolved as sister-group to Coleia Broderip (1835) and Polycheles Heller (1862). Karasawa et al. (2013) proposed closer relationships between Coleiidae and Polychelidae, which differs from our suggestion to include Tetrachelinae within
Coleiidae. Such a discrepancy is considered to represent an effect of limited sampling of Coleiidae in Karasawa et al. (2013). Indeed, Karasawa et al. (2013) focuses upon the relationships of all fossil lobsters rather than on those within polychelidans. More detailed phylogenetic analysis using also an outgroup outside Polychelida and a more extensive sampling of Coleiidae (still under development) will be required to assess the affinities of Tetrachela.

Tetrachela Reuss, 1858

Tetrachela Reuss, 1858: 5-6, pl. 1 figs 2-7.

Bolina - Bronn, 1858: 22-26, pl. 4 figs. 1-3. Beurlen, 1928: 187.

Tetrachela - Zittel, 1885: 686. - Van Straelen, 1928: 498-499. - Glaessner, 1929a: 382. - Glaessner, 1929b: 142-143. - Beurlen and Glaessner, 1930: 64, fig. 11. - Glaessner, 1930: 29. - Glaessner, 1931: 480. - Glaessner, 1965: 112. - Förster, 1967: 174. - Pinna, 1968: 103. - Glaessner, 1969: 468, figs 227 (18), 272. - Garassino and Teruzzi, 1993: 21. Garassino et al., 1996: 36-37. - Ahyong, 2009: 370, fig. 1A. - Schweitzer et al., 2010: 45. - Feldmann, et al. 2013b: 8, figs 5.3a, 5.3b. - Karasawa et al., 2013: 98 .

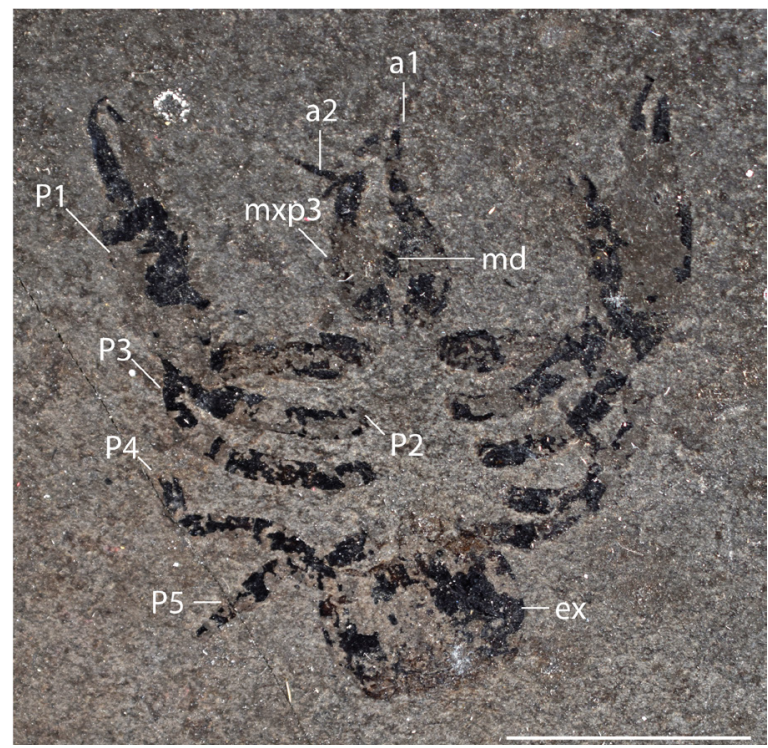

Figure 1. Lectotype of Tetrachela raiblana (Bronn, 1858), specimen without number, "Originaliensammlung" collection, institute of Geosciences, University of Heidelberg, ventral view, cross-polarized light. Abbreviations: a1, antennula; a2, antenna; ex, uropodal exopod; md, mandible; mxp3, third maxilliped; P1-P5, pereiopods 1 to 5. Scale bar: $10 \mathrm{~mm}$. Picture Klaus Will, Ruprecht-Karls-University Heidelberg, Copyright of picture: University of Heidelberg. 


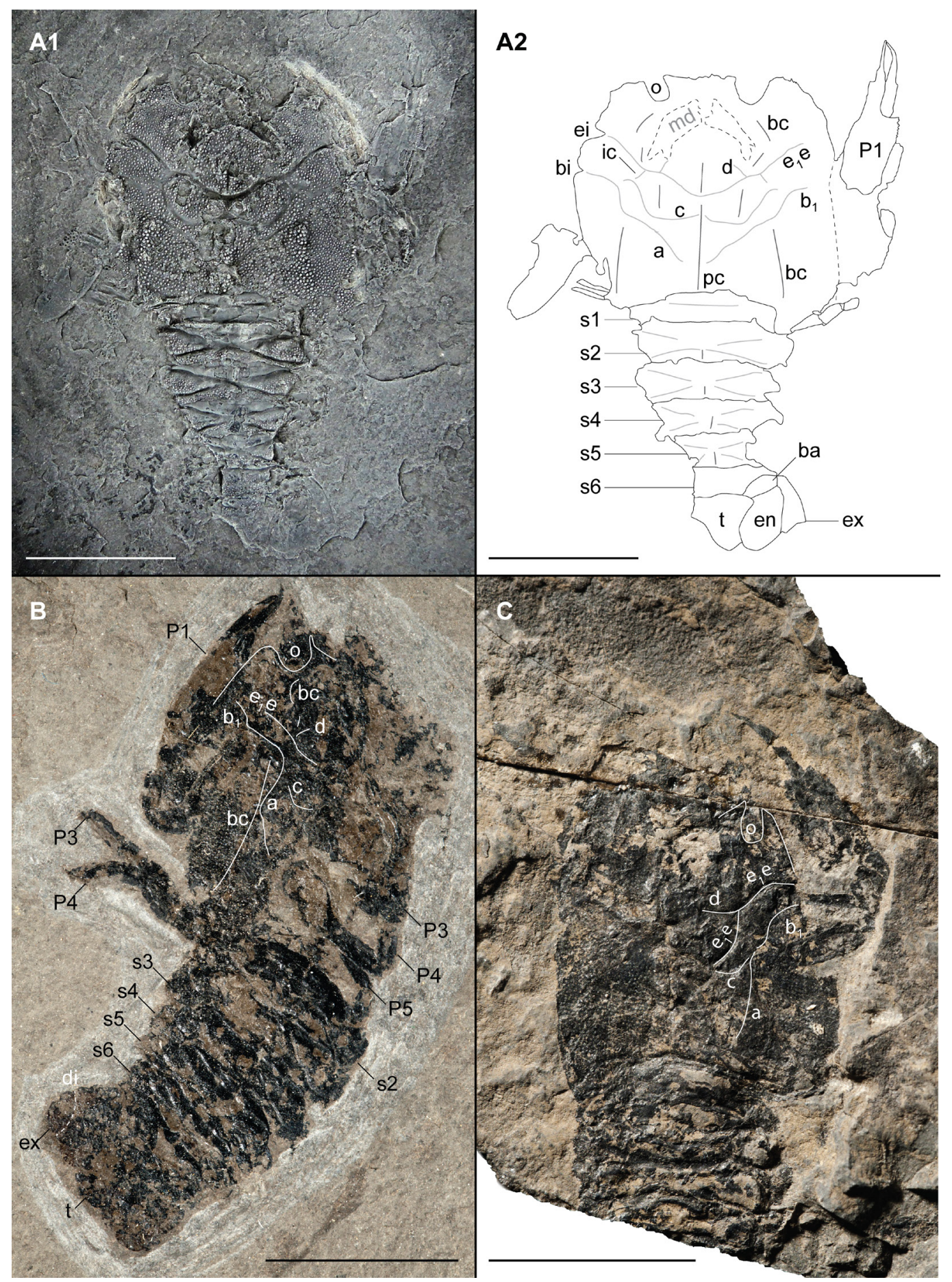

Figure 2. Tetrachela raiblana (Bronn, 1858). A, well-preserved specimen GBA 1930/002/002/01, coated with ammonium chloride (A1) and interpretative line-drawing (A2). B, specimen MFSNgp 19583, laterodorsal compression, cross-polarized light, with superimposed interpretative line-drawing. C, specimen MFSNgp 15538, dorsal view, cross-polarized light, with superimposed interpretative linedrawing. Abbreviations: a, branchiocardiac groove; $\mathbf{b}_{1}$, hepatic groove, ba, uropodal basipod; bc, branchial carina; bi, hepatic incision; $\mathbf{c}$, postcervical groove; $\mathbf{d}$, gastro-orbital groove; di, diaeresis; $\mathbf{e} \mathbf{e}$, cervical groove; ei, cervical incision; en, uropodal endopod; ex, uropodal exopod; ic, intercervical groove; md, mandible; $\mathbf{o}$, ocular incision; P1-P5, pereiopods 1 to 5; pc, postcervical carina; s1-s6, pleonites 1 to 6; t t telson. Scale bars: 10 mm. Photographs: Matúš Hyžný (A1), Denis Audo (B, C). Copyright of pictures: GBA (A1), MFSNgp (B, C). 
Stenochelus - Reuss, 1858: 2-4, pl. 1 fig. 1.

Eryon - Oppel, 1862: 10. - Woodward, 1881: 530.

- Knebel, 1907: 207. - Balss, 1924: 175 (pro parte).

Type species: Bolina raiblana Bronn, 1858, by monotypy.

Included species: monospecific genus.

\section{Distribution. Carnian (Italy, Austria).}

Diagnosis by Zittel (1885: 686). „Cephalothorax nie erhalten, ursprünglich sehr dünn, mässig breit, ebenso lang als das Abdomen. Hinterstes Kiemenfusspaar kräftig entwickelt, aber kurz. Die 4 vorderen Fusspaare des Thorax mit Scheeren; die Scheere des ersten mit einer grossen Hand und einem beweglichen Index. Telson hinten gerundet; die beiden Blätter des hintersten Schwimmfusses breit.“
Literal translation in modern terms. Cephalothorax never preserved, initially very thin, moderately wide, as long as the pleon. The last pair of pleopods well-developed, but short. The anterior four pairs of pereiopods chelate. First chela with a large palm and a movable index. Telson rounded, uropodal exopod and endopod broad.

Remarks. Tetrachela being the type and only genus of Tetrachelinae, its diagnosis is identical to that of the subfamily. See the present emended diagnosis.

Tetrachela raiblana Bronn, 1858

Figures 1-3, 4R

Bolina Raiblana Bronn, 1858: 22-26, pl. 4 figs. 1-3.

Stenochelus triasicus, Reuss, 1858: 2-4, pl. 1 fig. 1.

Bolina Raiblana - Beurlen, 1928: 187.

Tetrachela raiblana - Reuss, 1858: 5-6, pl. 1 figs 2-7.
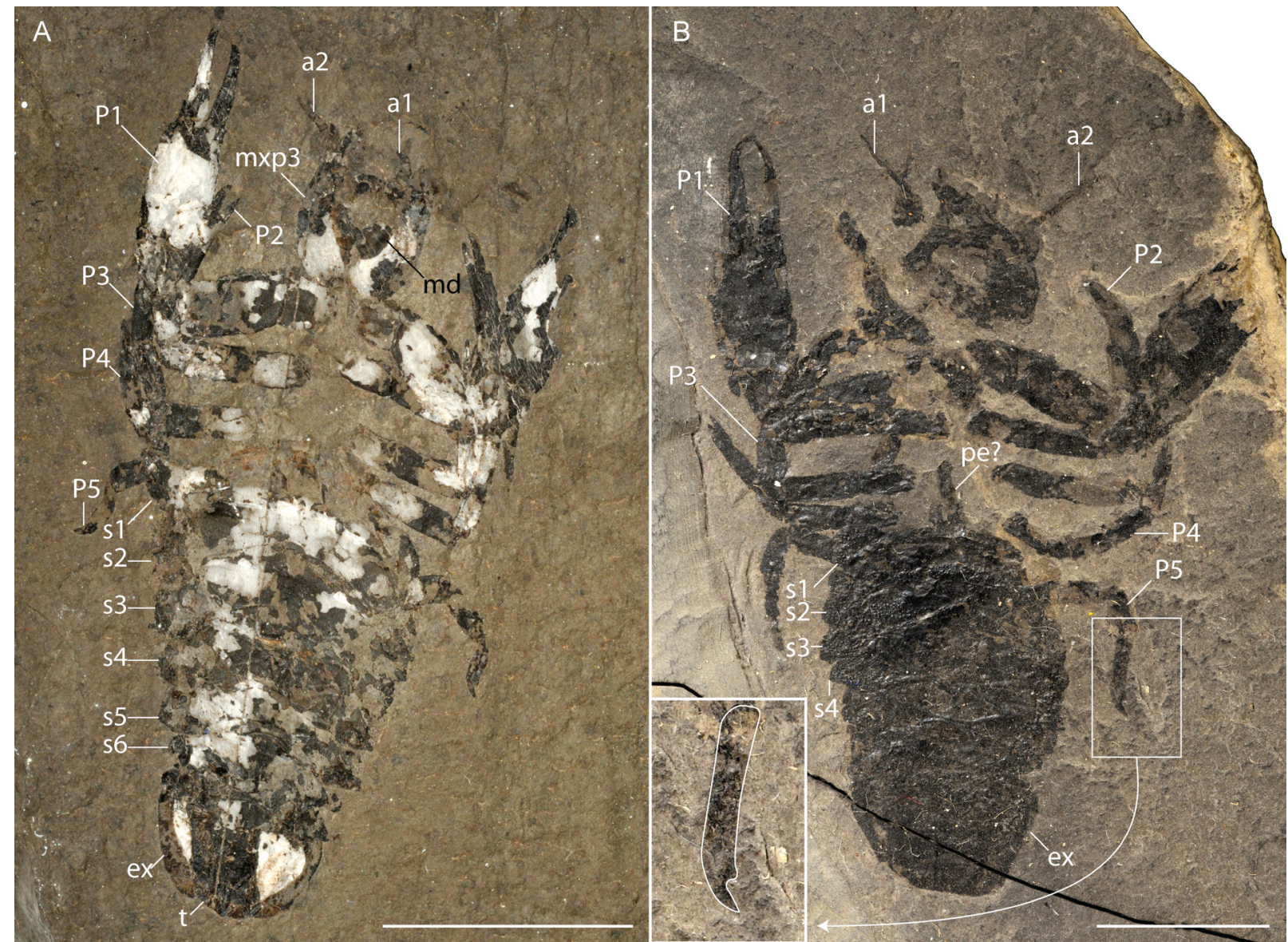

Figure 3. Tetrachela raiblana, appendages. A, specimen NHMUK 41870, ventral aspect, soaked in alcohol to enhance the contrast; B, specimen MPCM 2508, dorsal aspect, carapace missing, cross-polarized light. Abbreviations: a1, antennula; a2, antenna; ex, uropodal exopod; md, mandible; mxp3, third maxilliped; P1-P5, pereiopods 1 to 5; pe?, possibly the petasma; s1-s6, pleonites 1 to 6; t, telson. Scale bars: $10 \mathrm{~mm}$. Pictures: Denis Audo. Copyright of picture: NHMUK (A), MPCM (B). 
- Glaessner, 1929a: 382. - Glaessner, 1929b: 143144, pl. 9, fig. 1. - Beurlen and Glaessner, 1930: 64, fig. 11. - Glaessner, 1930: 29. - Glaessner, 1931: 480. - Glaessner, 1965: 112. - Förster, 1967: 174. Glaessner, 1969: 468, figs 227 (18), 272. - Garassino and Teruzzi, 1993: 21. - Garassino et al., 1996: 3637. - Ahyong, 2009: 370, fig. 1A. - Schweitzer et al., 2010: 45. - Feldmann et al., 2013b: 8, figs 5.3a, 5.3b. - Karasawa et al., 2013: 98.- Hyžný and Zorn, 2016 : 131, 138, pl.3 figs 1-2, pl. 15 fig. 2

Tetrachela raibliana - Pinna, 1968: 103 (incorrect spelling).

Eryon raiblanus - Woodward, 1881: 530. - Balss, 1924: 175.

Eryon Raiblianus - Oppel, 1862: 10. - Knebel, 1907: 207.

Type material. Lectotype herein designated: without collection number "Originaliensammlung" collection, Institute of Geosciences, University of Heidelberg (Figure 1 - examined).

Type locality. Cave del Predil (also known as "Raibl"), Friuli-Venezia Guilia, Italy (Bronn, 1858, Roghi, 2004).

Type age. Carnian.

Occurrence. Tetrachela raiblana has so far been reported only from thin shales of Cave del Predil (Italy) and the Polzberg Lagerstätte (Austria).

Additional material. 43 specimens: GBA 1858/004/0002/01, 1858/004/0002/02, 1930/002/0002/01 (Figure 2A). - NHMUK 41870 (Figure 3A), 41876, 44953, I.3256 (6 samples), one additional specimen withoutcollection number.-MCZ6252/1,MCZ6252/2, MCZ6252/3. - MFSNgp 01191, 15538 (Figure 2C), 15539-15540, 15594, 15598, 16884, 19249, 19583 (Figure 2B), 19587, 19591, 21032, 22860, 33976. MPCM 2508-2509 (part and counterpart; Figure 3B), 2512, 2514, 2517, 3541, 3543-3544, 4839, 4866, 7701. - SNSB-BSPG 1969 XII 2, 1969 XII 3.

Description. Outlines of carapace (cephalothoracic shield) (Figure 4R). - Dorsoventrally flattened carapace, subrectangular in outline in dorsal view; concave frontal margin (poorly preserved), placed slightly more anteriorly than the outer angle of ocular incision; anterolateral angle probably produced into a short spine (poorly preserved); lateral margin smooth, cut by ocular, cervical and hepatic incisions; deep U-shaped ocular incision, laterally enclosed by the lateral margin, opening anteriorly; anterolateral margin slightly convex, very slightly oblique; cervical and hepatic incisions opening in the anterior half of the lateral margin; deep subtriangular cervical incision; straight mediolateral margin, shorter than anterolateral margin; hepatic incision shallower than cervical incision; rounded posterolateral angle, extending slightly along pleonite 1 , contiguous to pleonite 1 lateral margin; concave posterior margin, wider than frontal margin.

Grooves and carinae of carapace (Figure 4R). Postrostral and postcervical carinae separated by cervical groove; postrostral carina short, limited to the posterior half or third between frontal margin and cervical groove; postcervical carina extending from cervical groove to posterior margin, cutting postcervical groove; short and raised anterior part of branchial carina (= postorbital carina?) curving inward anteriorly; posterior part of branchial carina rather short, separated from the anterior part by a large gap, marked from the branchiocardiac groove to the posterior margin; deep cervical groove marked across carapace, curving slightly near median line, cutting deeply median line; deep postcervical groove, almost joining hepatic-branchiocardiac grooves at their junction point, forming a transverse arc, joining median line without cutting it; deep intercervical groove extending from cervical groove toward postcervical groove, not merging with postcervical groove; deep hepatic groove extending from the hepatic incision (ventral side not preserved), and joining with branchiocardiac groove; branchiocardiac groove forming a right angle with hepatic groove, extending posteriorly toward the branchial carina, then oblique from the branchial carina toward median line, not reaching median line.

Pleon and telson. Pleon about as long as carapace, and slightly narrower than carapace; pleonite 1 shorter than others (poorly preserved); dorsal portion of terga (excluding tergopleura) of pleonites 2-5 with a pair of transverse groove converging medially and a slightly raised axial carina cutting posterior transverse groove; tergopleura of pleonites 2-5 apparently lanceolate (poorly preserved); dorsal portion of terga (excluding tergopleura) of pleonite 6 subtrapezoidal; tergopleura of pleonite 6 subtriangular and narrow; telson wellrounded distally.

Eye and cephalic appendages. Eye entirely contained in the ocular incision; antennula with two flagella carried by a short peduncle (poorly preserved); antenna with a short flagellum (poorly preserved); mandible composed of a large subtriangular protopodite carrying an incisive process with large 


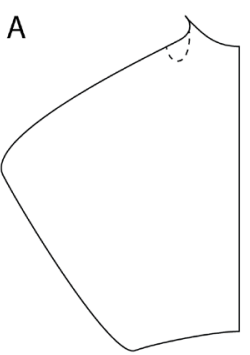

Adamanteryon

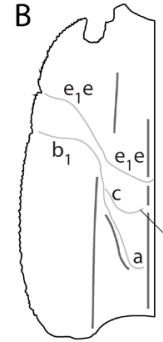

Antarcticheles

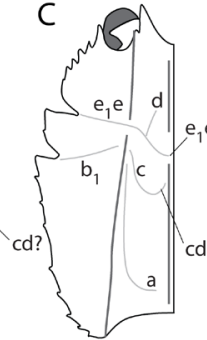

Coleia

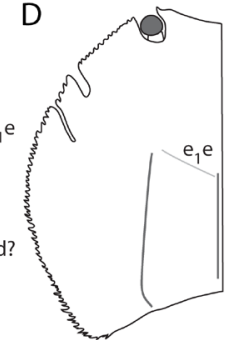

Cycleryon

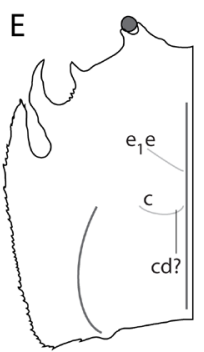

Eryon

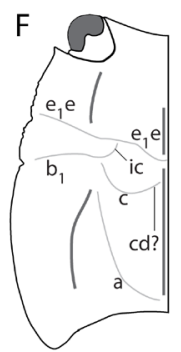

Gabaleryon

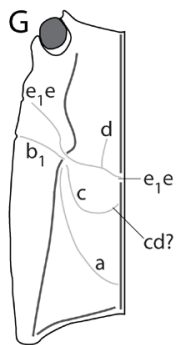

Hellerocaris

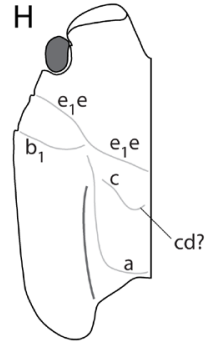

Knebelia

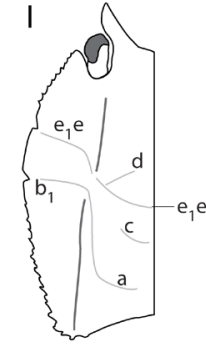

Palaeopentacheles

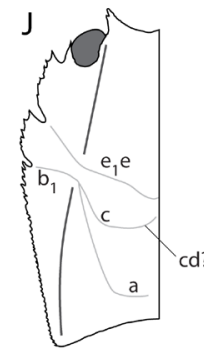

Palaeopolycheles

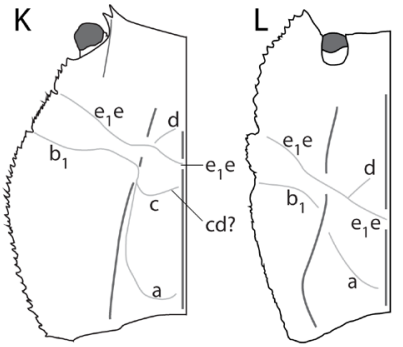

Proeryon

Pseudocoleia

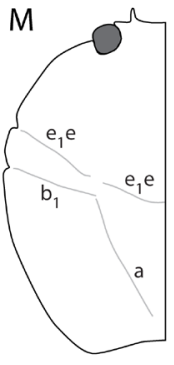

Rogeryon

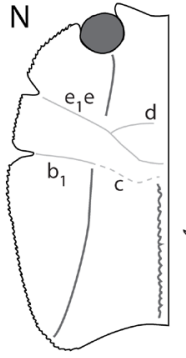

Rosenfeldia

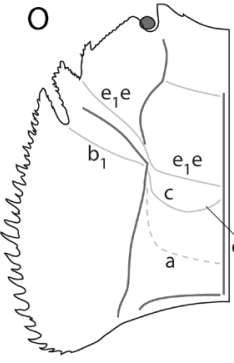

Soleryon

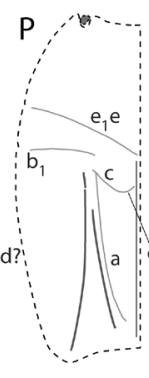

Tauricheles

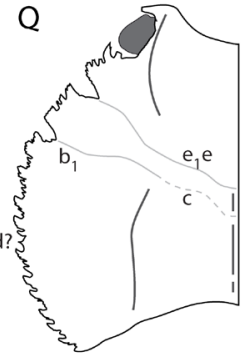

Tethyseryon

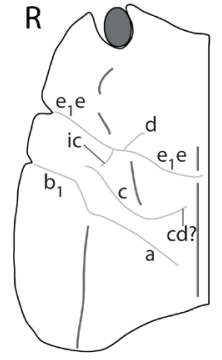

Tetrachela

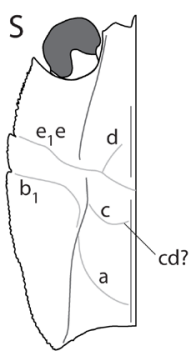

Tonneleryon

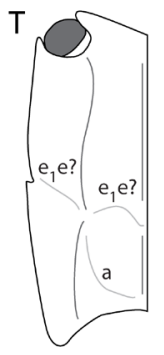

Tropifer

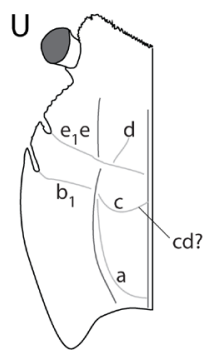

Voulteryon

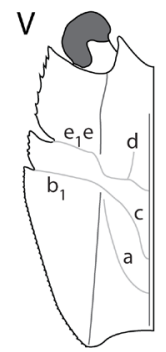

Willemoesiocaris

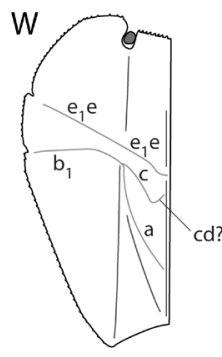

Woodwardicheles

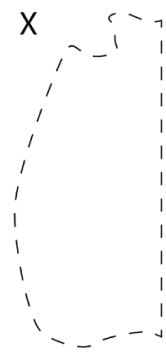

Wrangelleryon

Figure 4. Comparison of the general outline of carapaces, revised (right sides omitted, adapted from Audo et al. in press and Audo et al. 2017) of the type species of each genus of fossil Polychelida: A, Adamanteryon fourneti Audo, Schweigert, Saint Martin and Charbonnier, 2014; B, Antarcticheles antarcticus Aguirre-Urreta, Buatois, Chernoglasov and Medina, 1990; C, Coleia antiqua Broderip, 1835; D, Cycleryon propinquus (Schlotheim, 1822); E, Eryon cuvieri Desmarest, 1817; F, Gabaleryon coquelae Audo, Williams, Charbonnier and Schweigert, 2017.; G, Hellerocaris falloti (Van Straelen, 1923); H, Knebelia bilobata (Münster, 1839); I, Palaeopentacheles roettenbacheri (Münster, 1839); J, Palaeopolycheles longipes (Fraas, 1855); K, Proeryon hartmanni (Meyer, 1836); L, Pseudocoleia mazzolenii Garassino and Teruzzi, 1993; M, Rogeryon oppeli (Woodward, 1866); N, Rosenfeldia triasica Garassino, Teruzzi and Dalla Vecchia, 1996; O, Soleryon amicalis Audo, Charbonnier, Schweigert and Saint Martin, 2014; P, Tauricheles crymensis (Levitski, 1974); Q, Tethyseryon campanicus Bravi, Garassino, Bartiromo, Audo, Charbonnier, Schweigert, Thévenard and Longobardi, 2014; R, Tetrachela raiblana (Bronn, 1858); S, Tonneleryon schweigerti Audo, 2016; T, Tropifer laevis Gould, 1857; U, Voulteryon parvulus Audo, Schweigert, Saint Martin and Charbonnier, 2014; V, Willemoesiocaris ovalis (Van Straelen, 1923); W, Woodwardicheles neocomiensis (Woodward, 1881); X, Wrangelleryon perates Feldmann, Schweitzer and Haggart, 2013. Illustrations not to scale. 
median teeth framed by smaller anterior and posterior teeth.

Thoracic appendages (outline in ventral view). Third maxilliped (thoracopod 3) with an ischium roughly kidney-shaped and stocky distal podomeres; large chelate pereiopod 1 (P1: thoracopod 4); subtriangular P1 basis; stocky ischium with slightly rounded anterior and posterior margins; subrectangular P1 merus, longer than ischium; subtriangular, slightly rounded P1 carpus; stocky P1 propodus palm; straight P1 pollex with a slightly curved distal part; straight dactyl with a curved distal part; pereiopods 2 to 4 (P2P4: thoracopods 5-7) chelate, of decreasing size from P2 to P4; pereiopod 5 (thoracopod 8) ending in a small chela (only visible in two specimens, not preserved or unclear for others).

Pleonal appendages. Pleopods poorly preserved; uropod with short basipod carrying a rounded endopod strengthened by a median carina and a rounded exopod which posterolateral border is cut by the diaeresis forming an arc of circle.

Ornamentation. Dorsal surface densely covered by tubercles; smooth pereiopods, except for the outer margin of P1 propodus, which is covered by small tubercles.

Remarks. The description of Bolina raiblana Bronn, 1858 is based upon seven syntypes. Only one of these syntypes (Bronn, 1858 pl. 4, fig. 3) has been rediscovered in the "Originaliensammlung" collection housed in the Institute of Geosciences, University of Heidelberg. Other syntypes appear to have been lost or misplaced for a long time because they were not mentioned in the literature. Part of Bronn's collection is now in Harvard Museum of Comparative Zoology (MCZ) collections and does include specimens of Tetrachela, but they do not match individuals presented in Bronn (1858). Our search or inquiries at Geologischen Bundesanstalt (Vienna, Austria) or in the various collections, which might have housed the rest of this historic material, were not successful. Since Bronn (1858) illustrated only three of the seven syntypes, and because other crustacean species occur in the same outcrop, we designate the specimen herein illustrated in Figure 1 as the lectotype of Tetrachela raiblana (Bronn, 1858). This lectotype designation should limit future instability of nomenclature.

Reuss (1858) described Stenochelus triasicus based upon a single specimen from the same locality as Tetrachela raiblana. This specimen, which was not located and might also be lost, is known from a good illustration (Reuss, 1858: pl. 1, fig. 1). Oppel
(1862) considered $S$. triasicus as synonymous with T. raiblana. This opinion was followed by Glaessner (1929a, 1930). Detailed observation of the illustration in Reuss (1858) lead us to agree with this synonymy. Indeed, the general outline of carapace and the shape and position of carinae and grooves are identical to that documented for T. raiblana.

\section{Discussion}

\section{Nomenclature of grooves}

The first reconstruction of Tetrachela raiblana was provided by Glaessner (1929b: pl. 9, fig. 1). This reconstruction was refigured several times (Beurlen and Glaessner, 1930; Glaessner, 1969; Ahyong, 2009; Karasawa et al., 2013) without further examination, and was used as a basis for the phylogenetic analysis of Ahyong (2009) and possibly Karasawa et al. (2013). Based upon this reconstruction, T. raiblana appears to have a cephalothoracic groove pattern very different from that of other fossil and extant polychelidans, with several additional grooves. However, our reinvestigation reveals that this reconstruction was partially incorrect. Indeed, it seems these authors drew the branchiocardiac groove completely straight, instead of sinuous, and misinterpreted some fractures of the carapace for additional grooves.

From our observations, the grooves of T. raiblana are rather similar to that of other polychelidans (Figure 4). However, due to a larger gap between the anterior and posterior part of branchial carina, grooves are more marked, and their relations lead us to reconsider their nomenclature. Indeed, the transverse groove connected to the posterior incision is clearly linked to the branchiocardiac groove. Therefore, it suggests that the part of the groove extending from that posterior incision could be referred to as "branchiocardiac groove", and the corresponding incision as "branchiocardiac incision" (as proposed by Van Straelen, 1925; Glaessner 1969; Karasawa et al., 2013; and Feldmann et al., 2013b). It should not be referred as "postcervical groove" (contrary what is proposed by Galil, 2000; Ahyong and Brown, 2002; Ahyong and Galil, 2006; Ahyong and Chan 2004, 2008; Ahyong, 2009; Chang et al., 2013; Artuz et al., 2014; Audo et al., 2014a; 2014b; 2014c; Bravi et al., 2014; Jauvion et al., 2016; Audo, 2016; Audo et al., 2017). However, it could also be the "hepatic groove", since it is the prolongation of this particular groove, which extend 
from the junction of the antennal and cervical grooves and merges with branchiocardiac grooves in numerous crustaceans, such as glypheidans (Charbonnier et al., 2013: fig. 9; Figure 5C) and several groups of clawed lobsters (Tshudy and Babcock, 1997: their fig. 2; see also Figure 5D). Although this solution has not been proposed yet, it has a practical application, indeed, in Polychelidae, the groove emerging from the posterior incision on lateral margin is clearly disconnected from the branchiocardiac groove. We therefore propose to consider this groove as the dorsal portion of the hepatic groove, and the associated incision should be referred to as "hepatic incision". We note that this proposition contradicts the nomenclature sensu Glaessner (1960: 39), who considered the hepatic groove to be a part of the branchiocardiac groove. From our perspective, it is useful to distinguish both grooves, as they are not always linked.
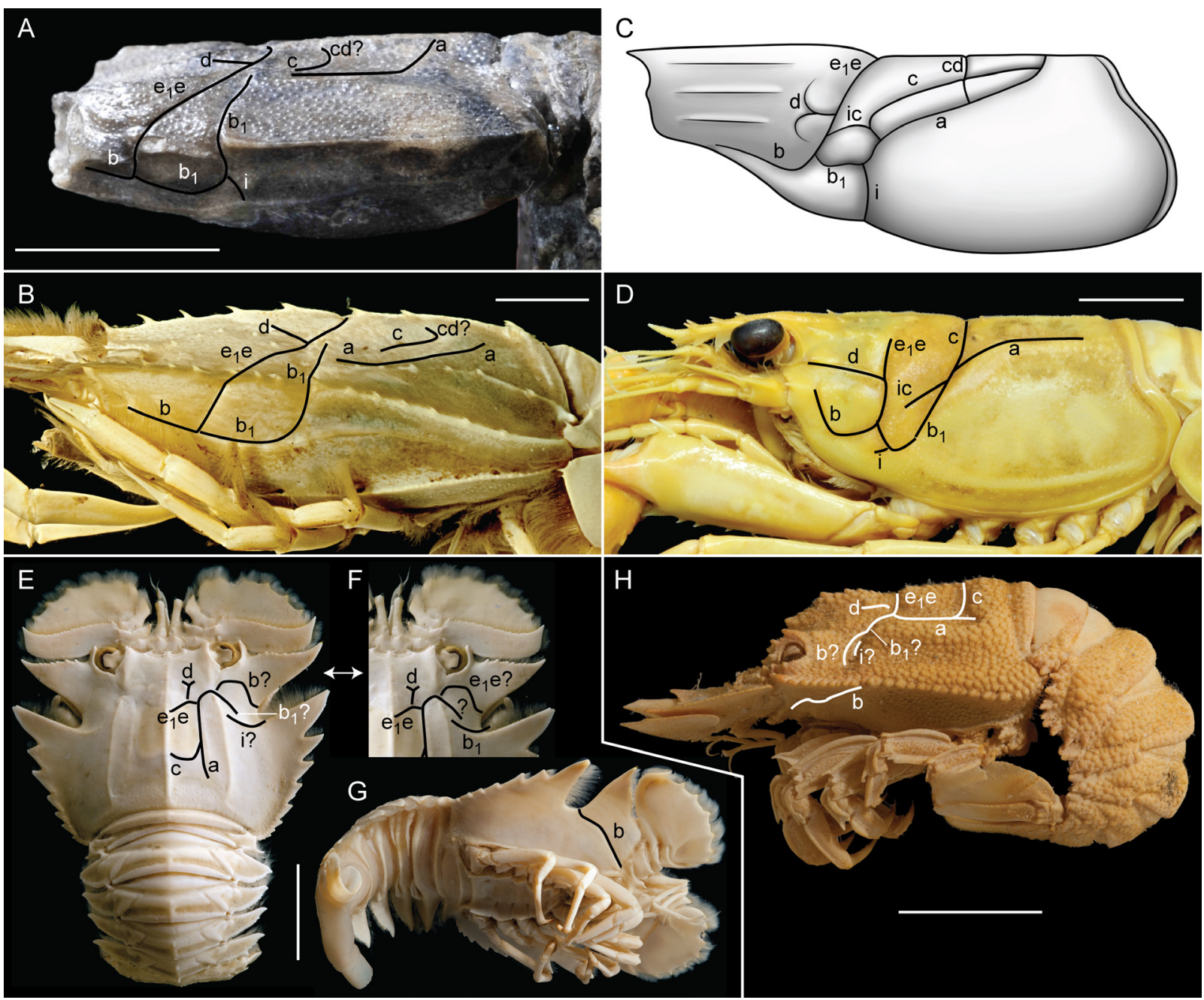

Figure 5. Homologies of carapace (shield) grooves in polychelidan lobsters and other reptantian crustaceans. A, Hellerocaris falloti (Van Straelen, 1923), MNHN.F.A47495, from the Callovian of La Voulte-sur-Rhône (France), lateral left view. B, Stereomastis surda (Galil, 2000), MNHN.IU2016.10672, female, from Big Bay (Vanuatu), trawled at about 700 metres (BOA 1 oceanographic expedition), lateral left view. C, Sketch of a glypheid lobster; D, Nephrops norvegicus (Linnaeus, 1758), MNHN.IU - unknown number, lateral left view. E-G, Ibacus alticrenatus Bate, 1888, MNHN.IU.2017.10263, male, from Bligh Water (Fiji Islands), trawled at about $380 \mathrm{~m}$ (MUSORSTOM 10 oceanographic expedition), dorsal view (E-F) and ventro-lateral view (G); H, Scyllarides squamosus (H. Milne Edwards, 1837), MNHN.IU.10262, male, origin unknown, lateral right view. Abbreviations: a, branchiocardiac groove; b, antennal groove; $\mathbf{b}_{1}$, hepatic groove; $\mathbf{c}$, postcervical groove; $\mathbf{c d}$, cardiac groove; cd?, possibly homologous with cardiac groove; $\mathbf{d}$, gastro-orbital groove; $\mathbf{e}$ e, cervical groove; $\mathbf{i}$, inferior groove; ic, intercervical groove; ic?, possibly homologous with intercervical groove. Scales: 10 mm (A-B), 20 mm (D-F). Images: Philippe Loubry (A), Denis Audo (B, D-H) and Charlène Letenneur (C). 


\section{Comparison with other Carnian polychelidans}

Coleia uzume is known from only five rather poorly preserved specimens from the early Carnian of Japan (Karasawa et al., 2003). Thus it is one of the oldest polychelidan species. Moreover it has been reported outside of Europe, where most fossil polychelidans have been discovered so far. For these reasons, it would be interesting to compare it to T. raiblana. Unfortunately, due to the preservation of the specimens, little can be used from the figures presented by Karasawa et al. (2003). The main difference between $C$. uzume and other polychelidans (including T. raiblana) appears to be the "inner branchial carina" which, however, most likely represents the posterior part of the ventral margin of the carapace superimposed to the dorsal carapace surface (the holotype and paratype of C. uzume are preserved in ventral aspect: Karasawa et al., 2003, figs $2.1,2.2$ ).

\section{Homologies of grooves between polychelidans and some other decapods}

The grooves on the surface of the carapace of many crustaceans are linked with internal structures, such as muscles and epimerite (Glaessner, 1960; Secrétan, 1964). The pattern formed by these grooves presents important similarities between groups (Figure 5), for instance, the longitudinal antennal and hepatic grooves, transverse cervical and postcervical grooves are extremely common in decapods. However, identifying the homologies between grooves is not easy.

In the case of polychelidans, the carapace grooves are present on the ventral and dorsal surfaces of the carapace. The homologies of these grooves with other decapod crustaceans may be hypothesized from their connections.

(1) The most anterior groove, only visible ventrally, connects the anterior margin to the cervical incision (Audo et al., 2014a, 2014c; Figures 4, 5A, 5B); from its position, it can only correspond to the antennal groove "b" occurring in many decapod crustaceans (Figure 5C, 5D, G-H; Boas, 1880; Van Straelen, 1925; Tsudy and Babcock, 1997; Tshudy and Sorhannus, 2003; Charbonnier et al., 2013), with a notable exception of brachyurans.

(2) The transverse groove arising from the antennal groove and passing through the first incision (not counting ocular incision) is considered to correspond to the cervical groove; its homology with the cervical groove "e $e_{1}$ " of other decapods can be established from its connection with antennal groove and gastro-orbital groove (Figure 5); it should not be confused with the transverse groove cutting median line and resembling a cervical groove in astacids and nephropids (the postcervical groove, although it is mistakenly referred to as "e $e_{1}$ " by Van Straelen, 1925: figs 25-27 and Chan and $\mathrm{Yu}, 1991: 21$, who remarked that the terminology is particularly confusing for the two transverse grooves on the carapace), this latter groove corresponds to the second transverse groove, that is part of the hepatic, branchiocardiac, and even postcervical grooves in polychelidans.

(3) A groove is often visible between the branchial carina and median line, where the cervical groove is inflexed, extending anteriorly and slightly toward median line; from the connection of this groove, it seems most likely to represent a gastro-orbital groove " $\mathrm{d}$ ", homologous to that found in many other decapods (Van Straelen, 1925; Tshudy and Sorhannus, 2003; Charbonnier et al., 2013; see Figure 5 - note that Van Straelen, 1925 in fig. 20 misinterpreted the anterior portion of the branchial carina as a gastro-orbital groove).

(4) On the ventral surface, the hepatic groove " $b_{1}$ " is aligned with the antennal groove, curving to pass through the hepatic incision, and stretch transversally to join the branchiocardiac groove in Tetrachela raiblana; this groove was discussed in detail in the previous section, its homology with the hepatic groove is supported by the connection with other grooves (Figure 4R) and its position; however, its boundaries and connections with the branchiocardiac and postcervical grooves are more difficult to assess and vary depending on authors and the group they discuss (more on this matter below). We note that this groove is not visible ventrally in the scyllarids illustrated herein (Figures 5G-H).

(5) On the dorsal surface, just posterior to the cervical groove, a groove lies between branchial carinae. This groove seems almost connected to hepatic and branchiocardiac groove in most species of polychelidans; from its position and connection (Figure 4), it seems homologous to the postcervical groove "c" of other decapods such as nephropids (Figure 5D) and astacids (Tshudy and Babcock, 1997; Tshudy and Sorhannus, 2000) or glypheideans (Charbonnier et al.; 2013; Figure 5C); we note that the postcervical groove of polychelidans in most species is curved anteriorly near median line, in eryonids, rare species of polychelids and Willemoesiocaris ovalis (Van Straelen, 1923), the groove is more straight and parallel to the branchiocardiac groove; it is possible 
that the curvature of this groove is in fact homologous to the cardiac groove "cd" of glypheidans (Charbonnier et al., 2013; see Figure 5C).

(6) In Tetrachela raiblana, a short groove connected to the cervical groove extends toward postcervical groove, it could be considered as the intercervical groove "ic" (Figure 4R). A similar groove may also occurs in Gabaleryon Audo, Williams, Charbonnier and Schweigert, 2017 (Figure 4F).

(7) The most posterior groove that arises from the hepatic groove, running almost parallel to the branchial carina before curving toward the median line is the branchiocardiac groove "a", since it is the last groove which delimits the branchial chamber, and consequently, no further groove can occur more posteriorly and laterally (Glaessner, 1960; see Figure 5).

(8) A small groove arising from the hepatic groove and extending ventrally is the inferior groove; it occurs in Soleryon amicalis (see Audo et al., 2014a) and Hellerocaris falloti (see Figure 5A), but not Stereomastis surda (Galil, 2000) (see Figure 5B).

In polychelidans and glypheidans, the distinction between hepatic, postcervical and branchiocardiac grooves are rather obvious. On the contrary, for some astacids, and nephropids (Figure 5D), the hepatic groove is merged with a deep groove that cuts the median line deeply, posterior to this groove (see Tshudy and Sorhannus, 2003: fig. 2). In these species, it is more difficult to judge where the postcervical joins the hepatic groove and where the branchiocardiac groove begins. From what is visible in allied species (see Tshudy and Babcock, 1997; Tshudy and Sorhannus, 2000), it seems that the hepatic groove extends rather high on the carapace before merging with the branchiocardiac and postcervical grooves. This situation is, in summary, similar to that described in polychelidans. For scyllarids, the general disposition of grooves between branchial carina is similar to that of glypheidans, polychelidans and nephropids (Fig. 5E-H). However, from the branchial carina to the lateral margin and on the ventral side of carapace, the groove pattern is rather different. For this reason, the homologies of grooves are far from clear. Figure 5 E-F proposes two alternative views on the homology of grooves between scyllarids and other decapods. A detailed study of scyllarids and other achelates is required to test our proposals, however, such a study is outside the scope of the present research. Despite this uncertainty of homologies, it is clear that scyllarids differ substantially from polychelidans by the groove pattern and/or carapace. This difference might be partially linked to the convergent flattening of the carapace in scyllarids and polychelidans, a process similar to "carcinization" (Scholtz, 2014).

\section{Taphonomy}

The absence of the carapace in most specimens of Tetrachela raiblana could imply they correspond to exuviae. Indeed, as discussed in detail by Audo (2016), polychelidan lobsters emerge from their old exoskeleton by rupturing the carapace along the median line and flipping it forward, which separates the carapace from the pleon. Despite the fact that most or all specimens of T. raiblana might correspond to exuviae, they still have their appendages and pleon associated (pleon is not visible in two specimens, for which the corresponding area is not prepared: MPCM 3544, NHMUK.3256). This association is interesting, because it was shown that the articulation between the anterior part of the exoskeleton and pleon is among the first to rupture in corpses (Allison, 1986, 1988; Plotnick, 1986). For exuvia and potential corpses (specimens which appear to be complete could correspond to corpses), we can postulate that finding the appendages and pleon closely associated implies that there was a limited transport and probably a rapid burial of these remains. These observations suggest that the studied individuals fossilised in the palaeoenvironment they inhabited (autochthonous) or were transported over only a short distance before final burial (parautochthonous).

\section{Palaeoenvironment}

The sediments forming the Carnian Predil Limestone lithologic unit of the Cave del Predil was deposited in a basinal environment (Rettori et al., 1998). The occurrence of Tetrachela raiblana in a deep-water palaeoenvironment is important in the broader context of polychelidan evolutionary history. Indeed, T. raiblana is one of the earliest polychelidans and several younger fossil species, for instance Tethyseryon campanicus Bravi, Garassino, Bartiromo, Audo, Charbonnier, Schweigert, Thévenard and Longobardi, 2014 and all species from Solnhofen-type outcrops were recorded from shallow water palaeoenvironments (Ahyong, 2009; Audo et al., 2014a, 2014b, 2016). However, T. raiblana shows well-developed ocular incisions which suggest the presence of developed and functional eyes. This character is surprising 
if we consider that $T$. raiblana lived in a deep palaeoenvironment. Indeed: (1) in modern genera, which live very deep (Galil, 2000), eyes are atrophied and non-functional (or at least almost not able to form detailed images since some species seems to react to light: Santucci, 1933); (2) Tauricheles crymensis (Levitski, 1974) and Woodwardicheles neocomiensis (Woodward, 1866), both from deep-water turbidites both have reduced ocular incisions (Audo et al., in press).

Consequently, either the basinal palaeoenvironment of Cave del Predil was still shallow enough for light to be perceptible, or T. raiblana had developed eyes despite being in a dark palaeoenvironment. Regarding this later explanation, it is good to note that decapod crustaceans such as some species of Glyphocrangon Smith, 1884 were reported from depths exceeding 800 meters, and yet retain developed eyes with marked pigmentation (Komai, 2011). Similarly, species of Metanephrops Jenkins, 1972 are known to live in deep water, yet retain eyes and cornea pigmentation (Chan and Hu, 1991; Holthuis, 1991). For instance, the specimen MNHN-IU-2008-10509 (KARUBAR oceanographic expedition) of Metanephrops neptunus (Bruce, 1965) trawled at approximatively $800 \mathrm{~m}$ also possesses developed eyes with strong cornea pigmentation (DA pers. obs. 2018).

If T. raiblana migrated temporarily in Cave del Predil basinal environment, it could be behaviour related to reproduction. Indeed, extant species are known to have sex-dependant distributions, probably linked to migration of females (Santucci, 1933; Firth and Pequegnat, 1971), who have to disperse their offspring (Bernard, 1953). Unfortunately, the preservation of most specimens does not allow determining the sex of animals. In fact, one specimen preserves what resembles a petasma (poorly preserved: Fig. 2B) and could therefore be a male.

\section{Palaeoecology}

Tetrachela raiblana, as with most other fossil polychelidans, differs distinctly from extant species by its morphology, and by the environment it lived in, which was probably deep, but not as deep as that of many extant species. However, from its overall aspect, we can already deduce it was mainly benthic. Indeed, it does not seem to have any part of its anatomy streamlined enough to be a good swimmer: its carapace is stout, probably rather thick, and is covered by distinct tubercles, its pereiopods are stout, and the pleon is quite wide. Such a morphology is quite distinct from that of polychelidans which might have been nektobenthic, or at least able to swim effectively such as Knebelia bilobata (Münster, 1839) (which seems to possess adaptations for swimming: Audo et al., 2014b) or Willemoesiocaris ovalis (Van Straelen, 1923) (which possesses a slender body and slender pereiopods: Audo et al., 2014c).

The diet of fossil polychelidans is perhaps even more complicated to study, for several reasons: (1), no direct evidence of predation has been reported so far; (2) only one specimen sufficiently well-preserved to preserve traces of its gut content is known, however, the fragments preserved in the gut are not identifiable (Jauvion et al., 2016); (3) comparison with extant species is complicated because they live in very deep water, which was probably not the case for many fossil species, and because their ecology is not well-known. Nevertheless, we observe that Tetrachela raiblana and most other fossil species present mandible incisor process similar in shape to that of extant species. Extant species are often considered to be scavengers or predators of small invertebrates (Firth and Pequegnat, 1971; Lagardère, 1973; Gore, 1984; Cartes and Abelló, 1992). Therefore, many fossil species, as Tetrachela raiblana, probably had a diet similar to that of extant Polychelidae. We remark, however, that T. raiblana, contrary to most extant species and many fossil species, has relatively short and stocky first pereiopods, similar to those of Rosenfeldia triasica Garassino, Teruzzi and Dalla Vecchia, 1996 (Audo et al., 2017). Tetrachela raiblana, as $R$. triasica, was therefore unlikely to be able to catch fast moving preys by ambushing them and rapidly deploying its first pereiopods, as some extant polychelidans probably do (Ahyong, 2009). Tetrachela raiblana was therefore more likely preying on sessile or slow-moving prey or was a scavenger.

\section{Conclusion}

Tetrachela raiblana is an important species for several reasons. First of all, to date, it is one of the oldest species of polychelidans reported. It also displays more distinctly the connections between cephalothoracic grooves, so that we were able, for the first time, to discuss the homologies between polychelidans and some other decapod carapace grooves. This new understanding of the homology of polychelidans with other decapods may prove useful for future phylogenetic work focusing on decapods. 


\section{Acknowledgements}

We are grateful to our four anonymous reviewers who contributed to make our manuscript clearer and also proposed to develop further a few aspects of this research. We are pleased to thank all the museum curators who gave us access to the specimens or provided images used in this study: Christina Ifrim (Institute of Earth Science, University of Heidelberg, Germany), Irene Zorn (GBA, Wien, Austria), Alexander Lukeneder (Naturhistorisches Museum, Wien, Austria), Lucas Simonetto, (MFSN, Udine, Italy), Fabio Dalla Vecchia (MPCM, Monfalcone, Italy), Claire Mellish (NHM, London, UnitedKingdom), Jessica Cundiff (MCZ, Cambridge, Massachusetts, United States of America), Paula Martin-Lefèvre and Laure Corbari (MNHN, Paris). We are also pleased to acknowledge Klaus Will (Ruprecht-Karls-University Heidelberg, Germany) for preparing the picture of the lectotype of T. raiblana. We are grateful to four anonymous reviewers whose critical comments helped to improve the manuscript considerably. The research of MH has been supported by VEGA 02/0136/15 and Hungarian Scientific Research Fund (OTKA K112708). The extant comparative material was collected during the KARUBAR (1991; PI Kasim Moosa), MUSORSTOM 10 (1998; PI Bertrand Richer de Forges), and BOA 1 (2005; PI Sarah Samadi) research cruises - part of the Tropical DeepSea Benthos programme. For station data and context of the expeditions, see https://expeditions.mnhn.fr/.

\section{References}

Aguirre-Urreta MB, Buatois LA, Chernoglasov GCB, Medina FA. 1990. First Polychelidae (Crustacea, Palinura) from the Jurassic of Antarctica. Antarctic Science 2: 157-162. http:// dx.doi.org/10.1017/S0954102090000207

Ahyong ST. 2009. The Polychelidan Lobsters: Phylogeny and systematics (Polychelida : Polychelidae). Pp. 369-396 in: Martin JW, Crandall KA, Felder DL, eds. Decapod crustacean phylogenetics. Crustacean Issues 18. Boca Raton, London, New York, CRC Press, Taylor and Francis Group.

Ahyong ST, Brown DE. 2002. New species and new records of Polychelidae from Australia (Crustacea: Decapoda). The Raffles Bulletin of Zoology 50: 53-79.

Ahyong ST, Chan TY. 2004. Polychelid lobsters of Taiwan (Decapoda: Polychelidae). The Raffles Bulletin of Zoology 52: 171-182.

Ahyong ST, Chan TY. 2008. Polychelidae from the Bohol and Sulu seas collected by PANGLAO 2005 (Crustacea: Decapoda: Polychelidae). The Raffles Bulletin of Zoology supplement 19: 63-70.

Ahyong ST, Galil BS. 2006. Polychelidae from the southern and western Pacific (Decapoda, Polychelida). Zoosystema 28: 757-767.

Ahyong ST, O’Meally D. 2004. Phylogeny of the Decapoda Reptantia: Resolution using three molecular loci and morphology. The Raffles Bulletin of Zoology 52: 673-693.

Allison PA. 1986. Soft-bodied animals in the fossil record: the role of decay in fragmentation during transport. Geology 14: 979-981. https://doi.org/10.1130/0091-7613(1986)14\%3C97 9:SAITFR\%3E2.0.CO;2
Allison PA. 1988. The role of anoxia in the decay and mineralization of proteinaceous macro-fossils. Paleobiology 14: 139-154. https://doi.org/10.1017/S009483730001188X

Artüz ML, Kubanç C, Kubanç SN. 2014. Stereomastis artuzi sp. nov., a new species of Polychelidae (Decapoda, Polychelida) described from the sea of Marmara, Turkey. Crustaceana 87: 1243-1257. https://doi.org/10.1163/15685403-00003353

Audo D. 2016. Tonneleryon, a new gregarious polychelidan lobster from the early Toarcian Posidonia Shale of Holzmaden (Germany). Neues Jahrbuch für Geologie und Paläontologie Abhandlungen 280: 285-298. http://dx.doi.org/10.1127/ njgpa/2016/0580

Audo D, Charbonnier S, Krobicki M. in press. Rare fossil polychelid lobsters in turbiditic palaeoenvironments. Journal of Systematic Palaeontology. https://dx.doi.org/10.1080/1477 2019.2017.1359690

Audo D, Charbonnier S, Schweigert G, Saint Martin J-P. 2014a. New eryonid crustaceans from the Late Jurassic Lagerstätten of Cerin (France), Canjuers (France), Wattendorf (Germany) and Zandt (Germany). Journal of Systematic Palaeontology 12: 459-479. http://dx.doi.org/10.1080/14772019.2013.7778 09

Audo D, Haug JT, Haug C, Charbonnier S, Schweigert G, Müller CHG, Harzsch S. 2016. On the sighted ancestry of blindness - exceptionally preserved eyes of Mesozoic polychelidan lobsters. Zoological Letters 2: 1-20. https:// dx.doi.org/10.1186/s40851-016-0049-0

Audo D, Schweigert G, Haug JT, Haug C, Saint Martin JP, Charbonnier S. 2014b. Diversity and palaeoecology of the enigmatic genus Knebelia (Eucrustacea, Decapoda, Eryonidae) from Upper Jurassic plattenkalks in southern Germany. Palaeontology 57: 397-416. http://dx.doi. org/10.1111/pala.12071

Audo D, Schweigert G, Saint Martin JP, Charbonnier S. 2014c. High biodiversity in Polychelida crustaceans from the Jurassic La Voulte-sur-Rhône Lagerstätte. Geodiversitas 36: 489-525. http://dx.doi.org/10.5252/g2014n4a1

Audo D, Schweigert G, Charbonnier S, Haug JT. 2017. Systematic revision and palaeobiology of Rosenfeldia triasica and Rogeryon oppeli nov. gen., nov. comb. (Eucrustacea, Polychelida). European Journal of Taxonomy 367: 1-23. https://doi.org/10.5852/ejt.2017.367

Audo D, Williams M, Charbonnier S, Schweigert G. 2017. Gabaleryon, a new genus of widespread early Toarcian polychelidan lobsters. Journal of Systematic Palaeontology 15: 205-222. http://dx.doi.org/10.1080/14772019.2016.1167 786

Balss H. 1924. Studien an fossilen Decapoden II. Paläontologische Zeitschrift 6: 174-184. http://dx.doi. org/10.1007/BF03041598

Bate SC. 1888. Report on the Crustacea Macrura collected by H.M.S. Challenger during the years 1873-1876, In: Wyville Thompson C. and Murray J. (eds), Report on the scientific results of the voyage of the H.M.S. Challenger during the years 1873-76 under the command of Captain Georges S. Nares R.N., F.R.S. and the late Captain Frank Tourle Thomson, R.N., Zoology 24., Neill, Edinburgh: 1-942.

Bengtson S. 2000. Teasing fossils out of shales with cameras and computers. Palaeontologia Electronica 3: 1-14.

Bernard F. 1953. Decapoda Eryonidae (Eryoneicus et Willemoesia). Dana-Report 37: 1-93. 
Beurlen K. 1928. Die Decapoden des Schwäbischen Jura mit Ausnahme der aus den oberjurassischen Plattenkalken stammenden. Beiträge zur Systematik und Stammesgeschichte der Decapoden. Palaeontographica 70: 115-278, pls 6-8.

Beurlen K. 1930. Vergleichende Stammesgeschichte, Grundlagen, Methoden, Probleme unter besonderer Berücksichtigung der höheren Krebse. Fortschritte der Geologie und Palaeontologie 8: 317-410.

Beurlen K. 1931. Die Besiedlung der Tiefsee. Natur und Museum 61: 269-278

Beurlen K, Glaessner MF. 1930. Systematik der Crustacea Decapoda auf stammesgeschichtlicher Grundlage. Zoologische Jahrbücher. Abteilung Systematik, Ökologie und Geographie der Tiere 60: 49-84.

Boas JEV. 1880. Studier over decapodernes Slægtkabsforhold. Videnskabelege Selskab Skrifter 6. Raekke, naturvidenskabeleg og mathematisk Afd. 1 (2): 25-210, pls 1-7.

Bouchet P, Héros V, Lozouet P, Maestrati P. 2008. A quartercentury of deep-sea malacological exploration in the South and West Pacific: Where do we stand? How far to go? Pp 9-40 in: Héros V, Cowie RH and Bouchet P, eds, Tropical DeepSea Benthos 25. Mémoires du Muséum national d'Histoire naturelle 196.

Boué A. 1835. Aperçu sur la constitution géologique des provinces Illyriennes. Mémoires de la Société Géologique de France 2: 43-89.

Bosellini A, Gianolla P, Stefani M. 2003. The Triassic platforms of the Dolomites (Northern Italy): their evolution and stratigraphic framework. Memorie di Scienze Geologiche 54: 111-114.

Bracken-Grissom HD, Ahyong ST, Wilkinson RD, Feldlmann RM, Schweitzer CE, Breinholt JW, Bendall M, Palero F, Chan T-Y, Felder DL, Robles R, Chu K-H, Tsang L-M, Kim D, Martin JW, Crandall KA. 2014. The emergence of lobsters: phylogenetic relationships, morphological evolution and divergence time comparisons of an ancient group (Decapoda: Achelata, Astacidea, Glypheidea, Polychelida). Systematic Biology 63: 457-479. http://dx.doi.org/10.1093/ sysbio/syu008

Bravi S, Garassino A, Bartiromo A, Audo D, Charbonnier S, Schweigert G, Thévenard F, Longobardi C. 2014. Middle Jurassic Monte Fallano Plattenkalk (Campania, southern Italy): first report on terrestrial plants, decapod crustaceans and fishes. Neues Jahrbuch für Geologie und Paläontologie Abhandlungen 272: 79-107. http://dx.doi.org/10.1127/00777749/2014/0398

Broderip WJ. 1835. Description of some Fossil Crustacea and Radiata. Proceedings of the Geological Society of London 2: 201-202.

Bronn HG. 1858. Beiträge zur triasischen Fauna und Flora der bituminösen Schiefer von Raibl. Neues Jahrbuch für Mineralogie, Geognosie, Geologie und Petrefakten-Kunde 1858: 1-32.

Bruce AJ. 1965. On a new species of Nephrops (Decapoda, Reptantia) from the South China Sea. Crustaceana 9: 274284.

Burkenroad MD. 1963. The evolution of the Eucarida, (Crustacea, Eumalacostraca), in relation to the fossil record. Tulane Studies in Geology 2: 2-17.

Cartes JE, Abelló P. 1992. Comparative feeding habits of polychelid lobsters in the Western Mediterranean deep-sea communities. Marine Ecology Progress Series 84: 139-150. http://dx.doi.org/10.3354/meps084139

Chan T-Y, Yu H-P. 1991. Studies on the Metanephrops japonicus group (Decapoda, Nephropidae) with descriptions of two new species. Crustaceana 60: 18-51.

Chang SC, Ahyong ST, Chan TY. 2013. New records of deepsea blind lobsters (Crustacea: Decapoda: Polychelidae) from Taiwan. Journal of Marine Science and Technology 21 suppl.: 8-14. http://dx.doi.org/10.6119/JMST-013-1219-2

Charbonnier S, Garassino A, Schweigert G, Simpson M. 2013. A worldwide review of fossil and extant glypheid and litogastrid lobsters (Crustacea, Decapoda, Glypheoidea). Mémoires $d u$ Muséum National d'Histoire Naturelle 205: 1-304.

Desmarest A-G. 1817. Crustacés fossiles. Pp. 495-519 in: Société de Naturalistes et d'Agriculteurs, eds. Nouveau Dictionnaire d'Histoire naturelle, appliquée aux Arts, à l'Agriculture, à l'Économie rurale et domestique, à la Médecine, etc. 7. Déterville, Paris.

Feldmann RM, Schweitzer CE, Haggart JW. 2013a. A new genus and species of polychelid lobster (Crustacea, Decapoda, Eryonidae) from the Early Jurassic (Hettangian) of British Columbia. Canadian Journal of Earth Sciences 50: 135-141. http://dx.doi.org/10.1139/cjes-2012-0120

Feldmann RM, Schweitzer CE, Karasawa H, Schweigert G, Garassino A, 2013b. Part R, Revised, Volume 1, Chapter 8G: Systematic descriptions: Infraorder Polychelida. Treatise Online 60: 1-10, 6 figs.

Firth RM, Pequegnat WE. 1971. Deep-sea lobsters of the families Polychelidae and Nephropidae (Crustacea, Decapoda) in the Gulf of Mexico and Caribbean Sea. Texas A and M University, Department of Oceanography: 1-106.

Forchielli A, Pervesler P. 2013. Phosphatic cuticle in thylacocephalans: a taphonomic case study of Austriocaris (Arthropoda, Thylacocephala) from the Fossil-Lagerstätte Polzberg (Reingraben shales, Carnian, Upper Triassic, Lower Austria). Austrian Journal of Earth Sciences 106: 46-61.

Förster R. 1967. Die reptanten Dekapoden der Trias. Neues Jahrbuch für Geologie und Paläontologie Abhandlungen 128: 136-194.

Fraas O. 1855. Beiträge zum obersten weissen Jura in Schwaben. Jahreshefte des Vereins für vaterländische Naturkunde in Württemberg 11: 77-107.

Galil BS. 2000. Crustacea Decapoda: review of the genera and species of the family Polychelidae Wood-Mason, 1874. Pp. 285-387 in: Crosnier A, ed., Résultats des campagnes MUSORSTOM, Volume 21. Mémoires du Muséum national d'Histoire naturelle 184.

Garassino A, Teruzzi G. 1993. A new decapod crustacean assemblage from the Upper Triassic of Lombardy (N. Italy). Paleontologia Lombarda Nuova serie 1: 3-27.

Garassino A, Teruzzi G, Dalla Vecchia FM. 1996. The macruran decapod crustaceans of the Dolomia di Forni (Norian, Upper Triassic) of Carnia (Udine, NE Italy). Atti della Società italiana di Scienze naturali e del Museo civico di Storia naturale in Milano 136: 15-60.

Glaessner MF. 1929a. Crustacea Decapoda. Pompeckj JF, ed. Fossilium Catalogus I: Animalia, 41, W. Junk, Berlin.

Glaessner MF. 1929b. Dekapodenstudien. Neues Jahrbuch für Mineralogie, Geologie und Paläontologie 63: 137-176, pls 6-10. 
Glaessner MF. 1930. Beiträge zur Stammesgeschichte der Dekapoden. Paläontologishe Zeitschrift 12: 25-42.

Glaessner MF. 1931. Eine Crustaceenfauna aus den Lunzer Schichten Niederösterreichs. Jahrbuch der Geologischen Bundesanstalt 81: 467-486.

Glaessner MF. 1960. The fossil decapod crustacea of New Zealand and the Evolution of the order Decapoda. Paleontological Bulletin 31: 1-79.

Glaessner MF. 1965. Vorkommen fossiler Dekapoden (Crustacea) in Fisch-Schiefern. Senckenbergiana Lethaea 46a: 111-122.

Glaessner MF. 1969. Decapoda. Pp. 399-533 in: Moore RC, ed., Treatise on Invertebrate Paleontology, Part R, Arthropoda 4.

Gore RH. 1984. Abyssal Lobsters, Genus Willemoesia (Palinura, Polychelidae), from the Venezuela Basin, Caribbean Sea. Proceedings of the Academy of Natural Sciences of Philadelphia 135: 1-11.

Gould C. 1857. Description of a new fossil crustacean (Tropifer lævis, C. Gould) from the Lias Bone-Bed. The quarterly Journal of the Geological Society of London 13: 360-363.

Griffith J. 1977. The Upper Triassic fishes from Polzberg bei Lunz, Austria. Zoological Journal of the Linnean Society 60: $1-93$.

Haan W, de. 1833-1850. Crustacea. In: von Siebold PhF, ed. Fauna Japonica sive descriptio animalium, quae in itinere per Japoniam, jusse et auspiciis superiorurn, qui summum in India Batavia Imperium tenent, suscepto, annis 1823-1830 collegit, notis observationibus et adumbrationibus illustravit. A. Arnz, Lugdunum Batavorum: 1-243.

Heller C. 1863. Die Crustaceen des südlichen Europa. Crustacea Podophthalmia. Wilhelm Braumüller, Wien: i-xi: 1-328, pls $1-10$.

Holthuis LB. 1991. Marine lobster of the world. FAO Fisheries Synopsis 125: 1-292.

Hopkin EK, McRoberts CA. 2005. A new Middle Triassic flat clam (Pterioida: Halobiidae) from the middle Anisian of North-Central Nevada, USA. Journal of Paleontology 79: 796-800.

Hornung T, Brandner R, Krystyn L, Joachimski MM, Keim L. 2007. Multistratigraphic constrains on the NW Tethyan „Carnian crisis“. In: Lucas SG, Spielmann JA, ed. The global Triassic. New Mexico Museum of Natural History and Science Bulletin 41: 59-67

Hyžný M, Zorn I. 2016. A Catalogue of the Type and figured Fossil Decapod Crustaceans in the Collections of the Geological Survey of Austria in Vienna. Jahrbuch der Geologischen Bundesanstalt 156: 127-177.

Jauvion C, Audo D, Charbonnier S, Vannier J. 2016. Virtual dissection and lifestyle of a 165-million-year-old female polychelidan lobster. Arthropod Structure and Development 45: 122-132. http://dx.doi.org/10.1016/j.asd.2015.10.004

Jenkins RJF. 1972. Metanephrops, a new genus of late Pliocene to recent lobster (Decapoda, Nephropidae). Crustaceana 22: 161-171.

Karasawa H, Takahashi F, Doi E, Ishida H. 2003. First notice of the family Coleiidae Van Straelen (Crustacea: Decapoda: Eryonoidea) from the upper Triassic of Japan. Paleontological Research 7: 357-362. http://dx.doi.org/10.2517/prpsj.7.357

Karasawa H, Schweitzer CE, Feldmann RM. 2013. Phylogeny and systematics of extant and extinct lobsters. Journal of Crustacean Biology 33: 78-123. http://dx.doi
org/10.1163/1937240X-00002111

Keim L, Brandner R, Krystyn L, Mette W. 2001. Termination of carbonate slope progradation: an example from the Carnian of the Dolomites, Northern Italy. Sedimentary Geology 143: 303-323.

Komai T. 2011. Further records of deep-sea shrimps of the genus Glyphocrangon (Crustacea: Decapoda: Caridea: Glyphocrangonidae) from the southwestern Pacific, with descriptions of two new species. Species Diversity 16: 113135.

Knebel W, von. 1907. Die Eryoniden des oberen Weissen Jura von Süddeutschland. Archiv für Biontologie 2: 195-233.

Lagardère J-P. 1973. Distribution des Décapodes dans le sud du Golfe de Gascogne. Revue des Travaux de l'Institut des Pêches Maritimes 37: 77-95.

Latreille PA. 1802. Histoire naturelle, générale et particulière, des Crustacés et des Insectes 3. F. Dufart, Paris.

Levitski EC. 1974. Fossil decapod crustaceans from the vicinity of the Bakhchisarai (the Crimea). Byulletin Moskovskogo Obshchestva Ispytatelei Prirody Otdel Geologicheskii 49: 101-119.

Linnaeus C. 1827. Systema naturæ per regna tria naturæ, secundum Classes, Ordines, Genera, Species cum characteribus, differentiis, synonymis, locis 1: 1-824.

McRoberts CA. 2001: Paleobiology of the Triassic "Flat Clam" Halobia in oxygen-deficient marine facies. Geological Society of America, Abstracts with Programs 33: A-8.

Meyer H, von. 1836. Beiträge zu Eryon, einem Geschlechte fossiler langschwänziger Krebse. Nova Acta Physico-Medica Academiae Caesareae Leopoldino-Carolinae Naturae Curiosorum 18: 263-283

Milne Edwards H. 1837. Histoire naturelle des Crustacés 2. Librairie encyclopédique de Roret, Paris: 1-532.

Münster G, Graf zu. 1839. Decapoda Macroura. Abbildung und Beschreibung der fossilen langschwänzigen Krebse in den Kalkschiefern von Bayern. Beiträge zur Petrefakten-Kunde 2: 1-88.

Nuova Raibl Soc. Coop. 2016. La storia della miniera. http:// www.minieradiraibl.it/la-storia-della-miniera/ Accessed 2 December 2016

Oppel A. 1862. Ueber jurassische Crustaceen (Decapoda macrura). Palaeontologische Mittheilungen aus dem Museum des koeniglich Bayerischen Staates 1: 1-12.

Pinna G. 1968. Gli Erionidei della nuova fauna sinemuriana a crostacei decapodi di Osteno in Lombardia. Atti della Società italiana di Scienze naturali e del Museo civico di Storia naturale in Milano 107: 93-134.

Plotnick RE. 1986. Taphonomy of a modern shrimp: implications for the arthropod fossil record. Palaios 1: 286-293. https:// dx.doi.org/10.2307/3514691

Rettori R, Loriga C, Neri C. 1998. Lower Carnian foraminifers from the type locality of the calcare del Predill (Raibl group, northeastern Italy). Rivista Italiana di Paleontologia $e$ Stratigrafia 104: 369-380.

Reuss AE. 1858. Ueber fossile Krebse aus den Raibler Schichten in Kaernthen. Beiträge zur Palaeontographie von Oesterreich 1: 1-6, pl. 1 figs 1-7.

Roghi G. 2004. Palynological investigation in the Carnian of the Cave del Predil area (Julian Alps, NE Italy). Review of Palaeobotany and Palynology 132: 1-35. http://dx.doi. org/10.1016/j.revpalbo.2004.03.001 
Santucci R. 1933. Biologia del fondo a "Scampi" nel Mar Ligure. I. Polycheles typhlops Heller. Memorie Reale Comitato talassografico italiano 199: 1-48.

Schlotheim EF, von. 1822. Nachträge zur Petrefactenkunde. Becker'schen Buchhandlung, Gotha.

Scholtz G. 2014. Evolution of crabs - history and deconstruction of a prime example of convergence. Contributions to Zoology 83: 87-105.

Scholtz G, Richter S. 1995. Phylogenetic systematics of the reptantian Decapoda (Crustacea, Malacostraca). Zoological Journal of the Linnean Society 113: 289-328. http://dx.doi. org/10.1006/zjls.1995.0011

Schweitzer CE, Feldmann RM, Garassino A, Karasawa H, Schweigert G. 2010. Systematic list of fossil decapod crustacean species. Crustaceana Monographs 10: 1-222.

Secrétan S. 1964. Les Crustacés décapodes du Jurassique supérieur et du Crétacé de Madagascar. Mémoires du Muséum national d'Histoire naturelle, Nouvelle série, Série C, Sciences de la Terre 14: 1-226.

Suess E, Mojsisovics E, von. 1867. Studien über die Gliederung der Trias- und Jura-Bildungen in den östlichen Alpen. Jahrbuch der Kaiser-Königlichen Geologischen Reichsanstalt 17: 553-582.

Tshudy D, Babcock LE. 1997. Morphology-based phylogenetic analysis of the clawed lobsters (family Nephropidae and the new family Chilenophoberidae). Journal of Crustacean Biology 17: 253-263. https://dx.doi.org/10.2307/1549275

Tshudy D, Sorhannus U. 2000. Jagtia kunradensis, a new genus and species of clawed lobster (Decapoda: Nephropidae) from the Upper Cretaceous (Upper Maastrichtian) Maastricht Formation, the Netherlands. Journal of Paleontology 74: 224-229. https://doi.org/10.1017/S0022336000031449

Tshudy D, Sorhannus U. 2003. Hoploparia, the best-known fossil clawed lobster (family Nephropidae), is a "wastebasket" genus. Journal of Crustacean Biology 23: 700-711. https:// doi.org/10.1651/C-2353

Van Straelen V. 1923. Les crustacés décapodes du Callovien de la Voulte-sur-Rhône (Ardèche). Comptes Rendus hebdomadaires des Séances de l'Académie des Sciences 175: 982-983.

Van Straelen V. 1925. Contribution à l'étude des Crustacés décapodes de la période jurassique. Mémoires de la Classe des Sciences de l'Académie royale de Belgique 2 e série 7: $1-462$.

Van Straelen V. 1928. Sur les crustacés décapodes triassiques et sur l'origine d'un phylum de brachyoures. Bulletins de la Classe des Sciences 8 ${ }^{\mathrm{e}}$ série 14: 496-516.

Woodward H. 1866. Notes on the species of the genus Eryon Desmarest from the Lias and Oolite of England and Bavaria. Quarterly Journal of the Geological Society of London 22: 494-502. http://dx.doi.org/10.1144/GSL.JGS.1866.022.0102.40

Woodward H. 1881. Contribution to the study of fossil Crustacea. The Geological Magazine, new series Decade II 8: 529-534. http://dx.doi.org/10.1017/S0016756800159217

Zanche V, de, Gianolla P, Roghi G. 2000. Carnian stratigraphy in the Raibl/Cave del Predil area (Julian Alps, Italy). Eclogae geologicae Helvetiae 93: 331-347.

Zittel KA, von. 1885. Handbuch der Palaeontologie 1 (2). Mollusca und Arthropoda. R. Oldenbourg, München and Leipzig: 893 p.
Received: 12 December 2017

Revised and accepted: 15 March 2018

Published online: 4 May 2018

Editor: R. Vonk 